\title{
Acoustic Method of Colorado Beetle Elimination and It's Realization
}

\author{
Galyna Ivanovna Sokol, Tatyana Leonidovna Savchuk, Vladislav Valerievich Anisimov \\ Faculty of Physics and Technology, Dnipropetrovs'k National University of name Oles Gonchar, Dnepropetrovsk, Ukraine
}

Email address:

gsokol@ukr.net (G. I. Sokol), majaj@mail.ru (T. L. Savchuk), anisimov.vlad@gmail.com (V. V. Anisimov)

\section{To cite this article:}

Galyna Ivanovna Sokol, Tatyana Leonidovna Savchuk, Vladislav Valerievich Anisimov. Acoustic Method of Colorado Beetle Elimination and It's Realization. European Journal of Biophysics. Vol. 3, No. 5, 2014, pp. 38-42. doi: 10.11648/j.ejb.20150305.12

\begin{abstract}
In this article the specific influence of the acoustic waves on the organisms living beings is examined. It is known that the most important resonance frequencies of human organs are in the frequency range $0.5-20 \mathrm{~Hz}$. And protection against the harmful acoustic waves on the human body may be only if a person is located in an acoustic field with a frequency, which does not coincide with the resonant frequency of the person. On the contrary, we can use the influence of acoustic fields on organisms of plant pests with the frequency that corresponds to the resonant frequency of body of pests. Then the acoustic field will have a devastating effect on the plant pest. In the laboratory the deaths of the Colorado beetle under the influence of vibratory oscillation and acoustic vibrations were detected. The method and the device for its implementation were developed and described below. The author has registered in the Patent Office of Ukraine "Acoustic Solution Colorado Beetle and Device for Performing" № 25548 A 01 M 1/04, 1/18 October 30, 1998. The elimination of the Colorado beetle by influencing its body by acoustic vibrations leads to a decrease in complexity of operation while excluding toxicity. The experiment was conducted under the conditions of agricultural area using a model of the transmitter.
\end{abstract}

Keywords: Negative, Influence, Acoustic Oscillations, Frequency, Body, Individual Organs, Colorado Beetle

\section{Introduction}

It is commonly known that vibrations and acoustic oscillations can cause both negative and positive influence on living organisms. In particular, the harmful effect of vibration on people working with jack hammers and on people in the vehicles is widely described in literature in details. There are some data about the harmful effect of both acoustic noises and tone acoustic oscillations on the human organism $[1,2]$. Specific influences of low frequency acoustic waves on human beings are reviewed.

The fact that resonance has the power to convert sound wave pressure into mechanical motion is widely known and can be very useful. Resonant objects want to vibrate at their natural frequency and do so with the slightest provocation. They resist vibration at frequencies other than their natural frequency. A very small amount of energy at the proper frequency can result in major motion and even damage of resonant objects. Hence, it is possible to make a conclusion that there are prerequisites for creation acoustic method having harmful or even lethal effect on insects, particularly on Colorado beetle.
It is possible to eliminate the Colorado beetle by exposing to acoustic oscillation. The method and devices for its implementation have been developed and described hereinafter.

\section{Development of the Acoustic Method}

During the investigation of the vibrations or acoustical oscillations of the harmful insect as whole biological object or its separate organs under the influence of outer mechanical disturbance, the body should be considered as a system constructed of mechanical elements having inertial, elastic, damping properties [1]. The type and the character of equations describing movements of the viscoelastic system with the mass $m$ and stiffness $k$ is the typical equation of oscillation:

$$
\ddot{\delta}+(c / m) \dot{\delta}+(k / m) \delta=a(t)
$$

Hence, the development of the method of the destruction of bodies, organs, tissues and similar object is possible by the application of the influence of an oscillating type [2]. 
So, the elimination of the Colorado beetle as a biological object being a viscoelastic system, is possible by its exposure to vibration and acoustic oscillation. It is necessary to know the data relating to the mass of a beetle and its stiffness. Also, a question about the frequency band of the exposure arises.

The resonance frequency of the body as a viscoelastic system is determined according to the following formula:

$$
\mathrm{f}_{\mathrm{RES}}=\frac{1}{2 \pi} \sqrt{\mathrm{k} / \mathrm{m}}
$$

The author carried out the experiments on determination of the mass and the stiffness of the Colorado beetle body.

We supposed that body of a beetle as system from the mechanical elements possessing inertial, elastic and damping properties is considered. In this case the system has own resonant frequency $f_{\varkappa}$. Then destruction of a harmful insect as the biological object which is viscoelastic system, is possible by the influence on it of vibrating or acoustic oscillations on resonance frequency. It will lead to severance of a body, resources and individual organs of the beetle.

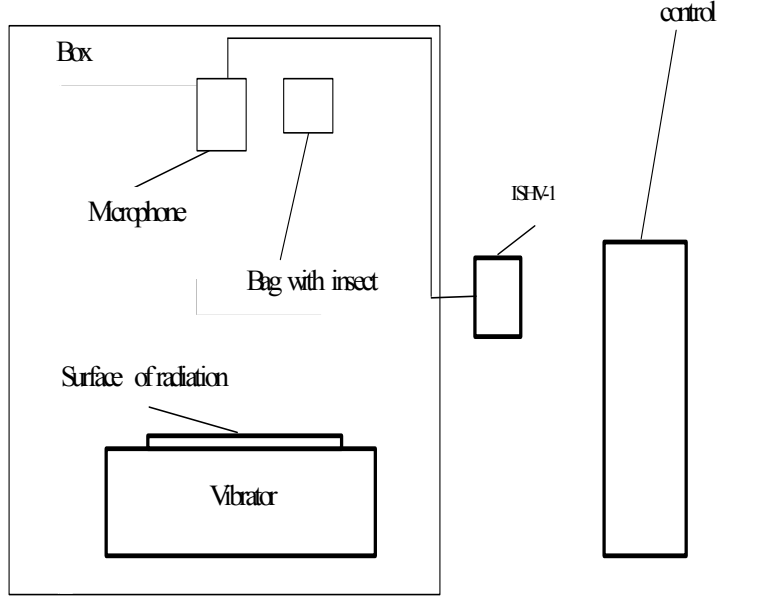

Figure 1. Block-Scheme of the experimental stand
Vibrostand UVE-100/5-3000 and scales were used at tests. Preliminary each of examinees of insects has been weighed with accuracy $\pm 0,005 \Gamma$, marked by a red paint. Each tested insect was in a gauze sack which fastened to a table of vibrostand. Block-Scheme of the experimental stand is shown on Fig. 1.

After influence of vibrations each insect has been examined and spread out on capacities with others, two more, not put on trial, insects. Necks of capacities were fastened by a gauze fabric. The subjects of the experiment were 8 beetles with the mass of $100-200 \mathrm{mg}$. The frequency of the oscillation effect was $500-2500 \mathrm{~Hz}$. The time of the acoustic waves effect was 2 min. On the basis of the previously gathered data the biological death is registered for the beetle weighing $100 \mathrm{mg}$ after the influence of the $1500 \mathrm{~Hz}$ frequency vibration with noise level of $120 \mathrm{~dB}$ in 4 hours after influence of vibrations. The repeated examination of the beetles after 24 hours showed the biological death of all the beetles exposed to acoustic influence. Using the described experiment, the resonance frequency for the beetle's body was determined.

Acoustic waves put mechanical pressure upon beetle's body and organs. That leads to rupture of fabrics of a body go separate organs. Thus, destruction of Colorado beetle is reached.

Modes of influence by vibrations on individuals of a bug (table 1).

Table 1. Modes of influence by vibrations on insects a beetle.

\begin{tabular}{l|lll}
\hline № & $\begin{array}{l}\text { Frequencies of } \\
\text { influence }(\mathbf{H z})\end{array}$ & Reaction of beetles & Mass of beetles (mg) \\
\hline 1 & 500 & Creep; active & 200 \\
2 & 700 & Move & 170 \\
3 & 800 & Creep; active & 150 \\
4 & 1000 & Paws twitchily cramp; & 130 \\
& & moustache falls off & \\
5 & 1200 & Feebly move, paws & 120 \\
6 & 1500 & unscrewed & 100 \\
7 & 2000 & Paws broken & 190 \\
8 & 2000 & Active; move & 145 \\
\hline
\end{tabular}

On the basis of these data the stiffness of the Colorado beetle body is estimated as: $k=8.86 \times 10^{6} \mathrm{~N} / \mathrm{m}$.

Influence conditions of acoustic oscillations on a body of a beetle in a box are shown in table 2.
This principle has been put in the experimental researches. In first time the mass $m_{\varkappa}$ and resonance frequency $f_{\varkappa}$ were determined. Than in second time the rigidity of a body of a Colorado beetle was defined in accordance with calculation.

Table 2. Influence conditions of acoustic oscillations on a body of a beetle in a box

\begin{tabular}{|c|c|c|c|c|c|c|}
\hline № & $\begin{array}{l}\text { Frequency } \\
\text { influences }(\mathrm{Hz})\end{array}$ & Reaction of beetles & $\begin{array}{l}\text { Mass of beetles } \\
\text { (Mg) }\end{array}$ & $\begin{array}{l}\text { Time of } \\
\text { action (min) }\end{array}$ & $\begin{array}{l}\text { Level of sound } \\
\text { pressure (dB) }\end{array}$ & $\begin{array}{l}\text { Distance from the } \\
\text { generator }(\mathrm{m})\end{array}$ \\
\hline 1. & 1000 & Creeps upwards from the generator, it is active & 100 & 3 & 107 & 0,7 \\
\hline 2. & 1000 & Creeps upwards from the generator, it is active & 100 & 3 & $110-112$ & 0,6 \\
\hline 3. & 1000 & Creeps, it is active & 100 & 3 & $115-117$ & 0,6 \\
\hline 4. & 1000 & The beetle without life signs & 110 & 2 & 120 & 0,2 \\
\hline 5. & 1000 & Poorly moves with hinder legs & 120 & 2 & $115-120$ & 0,2 \\
\hline 6. & 900 & The beetle is active & 120 & 2 & $105-117$ & 0,2 \\
\hline 7. & 1000 & The beetle moves & 120 & 3 & 117 & 0,2 \\
\hline 8. & 1000 & Languid, creeps & 100 & 3 & 119 & 0,2 \\
\hline 9. & 1100 & The beetle is active & 100 & 3,5 & 95 & 0,2 \\
\hline 10. & 900 & The beetle is active & 100 & 3 & 119 & 0.2 \\
\hline
\end{tabular}


Colorado Beetle' Elimination and Device for its Performance" № 25548 A $01 \mathrm{M} \mathrm{1/04,1/18} \mathrm{October} 301998$ to the patent department of the Ukraine [3]. The invention refers to agriculture, in particular to the means and devices for the harmful insects' elimination. The task of improving of the means of the Colorado beetle's elimination by way of influence of the acoustic oscillations on the beetle's body and organs was put into a basis of the invention; that leads to reduction of the laboriousness of the work, relating the Colorado beetle' elimination, with a simultaneous exclusion of toxicity under performing such work.

\section{Device}

The generator develops a voice-frequency acoustic signal of certain amplitude and frequency which moves on the amplifier on a cable network, and then further on loudspeaker. Loudspeaker radiates acoustic waves in the air environment. Frequency is equal to frequency of the voice-frequency acoustic signal developed by the generator. The amplitude of sound pressure depends on amplitude of an electric signal and from degree of its strengthening [3]. On the Fig. 2 the scheme of the device is presented.

The method is efficient when the generator develops a signal which frequency is equal to own frequency of a body of the beetle or own frequency of its separate organs. For example, heart. It leads to rupture of fabrics of a body of a beetle or its separate organs, and further and to destruction of a beetle. Waves extend to a soil surface, operate on the insects that have fallen to soil and break off their fabrics [4 - 6].

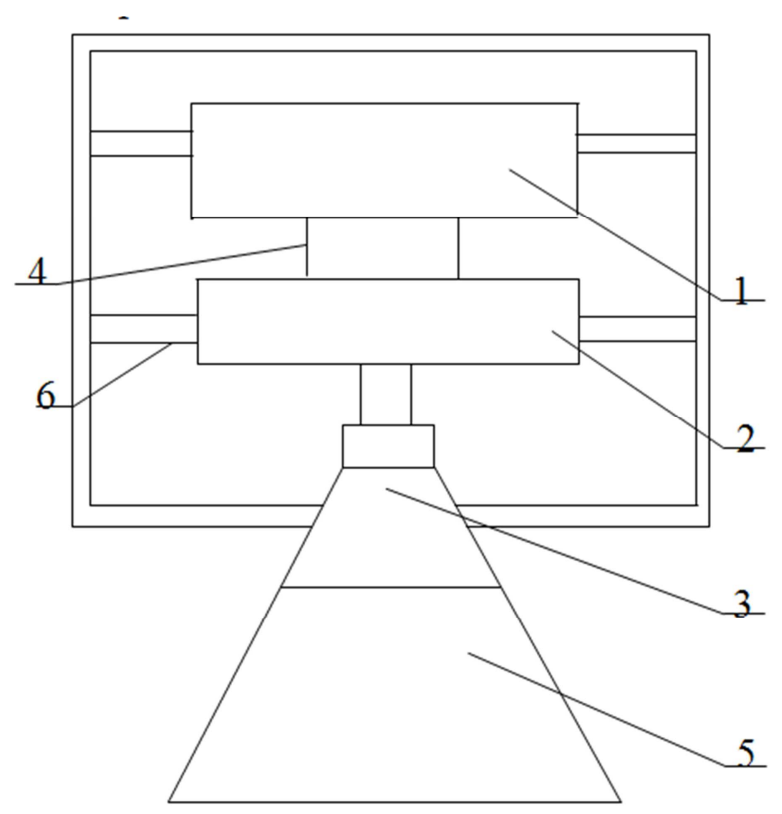

Figure 2. The device scheme.

\footnotetext{
1 - signals generator;

2 - amplifier;

3 - loudspeaker;

4 - cable network;

5 - concentrator;

6 - frame.
}

\section{Method Implementation and Generator Model Operating in Conditions of Agricultural Area}

The analyzing and measuring complex see on Fig. 3.

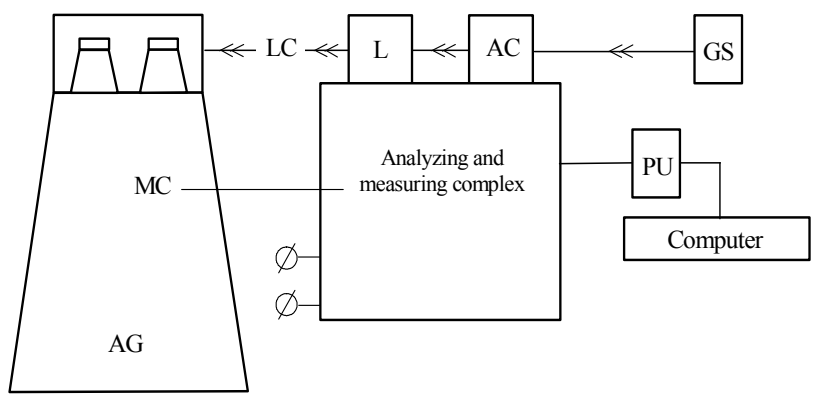

Figure 3. Scheme of an analyzing and measuing complex.

AG - acoustic generator,

LC - low-frequency cable (length $30 \mathrm{~m}$ ),

$\mathrm{L}$ - linkage,

AC - capacity amplifier,

GS - generator setting,

$\mathrm{MC}$ - microphone,

PU - power unit.

Fig. 4 presents acoustic generator model which is a part of the analyzing and measuring complex.

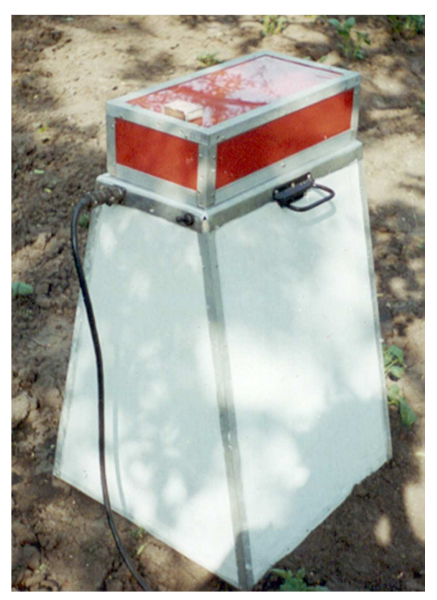

Figure 4. Acoustic generator model.

At carrying out tests following problems in the conditions of a country site (in field conditions) were solved:

1) test of working capacity of an operating model of the acoustic generator;

2) working capacity test in conditions of the general scheme of devices (the generator of signals electric, the amplifier, a cable network, the acoustic generator);

3) definition of mass of beetles;

4) definition sound pressure level;

5) definition of acoustic and electric capacities of the acoustic generator.

Into the equipment complete set enter: the generator setting GS, the amplifier of capacity AC, linkage L. 
The acoustic generator $(\mathrm{AG})$ is collected on the basis of two electrodynamic radiators 25 - GS and supplied by the concentrator of acoustic energy.

The potato bush, on which there were wreckers, was completely covered. Setting generator GS works in a range of frequencies of $20 \mathrm{~Hz}-200 \mathrm{kHz}$. It is the industrial sample of the generator of type GS-33. Analyzing and the computer complex consists of power unit BS, microphone $\mathrm{MC}$ and the personal computer. All devices are supplied from a network with voltage of $220 \mathrm{~V}$. The measured height of bushes of a potato has made $18 \mathrm{~cm}$. The microphone see has been established on a support over a potato bush on distance of 25 $\mathrm{cm}$ from an earth surface (i.e. on distance of $45 \mathrm{~cm}$ from a radiator surface) and has been directed towards radiating surface AG [5]. Axis MC coincided with an axis of the left radiator in gauging № 1-7. Axis $\mathrm{MC}$ coincided with axis $\mathrm{AG}$ in gauging №8 (see table 3).

The measured mass of beetles that were under the influence of the acoustic waves has made 100-200 mg. Irradiation time has made 1-4 minute. On a bush of a potato during an irradiation in each new mode of tests was on 3 beetles. Frequency of acoustic influence made during experiments $800-1500 \mathrm{~Hz}$. After beetles have been the subject to acoustic influence, they have been spread out in separate capacities according to number of spent experiment and left in them without a forage. The capacity neck was closed by a gauze fabric.

\section{Results}

Research data is presented in table 3 .

Table 3. Results of the experimental researches carried out in the conditions of a country site.

\begin{tabular}{|c|c|c|c|c|}
\hline № & $\begin{array}{l}\text { Frequency } \\
\text { radiations }(\mathrm{Hz})\end{array}$ & $\begin{array}{l}\text { Time of an } \\
\text { irradiation of } \\
\text { beetles (min) }\end{array}$ & $\begin{array}{l}\text { Quantity of } \\
\text { beetles }\end{array}$ & $\begin{array}{l}\text { Mass of } \\
\text { beetles (mg) }\end{array}$ \\
\hline \multirow{3}{*}{1} & \multirow{3}{*}{1500} & \multirow{3}{*}{2} & \multirow{3}{*}{3} & 100 \\
\hline & & & & 150 \\
\hline & & & & 110 \\
\hline \multirow{3}{*}{2} & \multirow{3}{*}{1500} & \multirow{3}{*}{1} & \multirow{3}{*}{3} & 200 \\
\hline & & & & 150 \\
\hline & & & & 100 \\
\hline \multirow{3}{*}{3} & \multirow{3}{*}{1500} & \multirow{3}{*}{4} & \multirow{3}{*}{3} & 100 \\
\hline & & & & 100 \\
\hline & & & & 120 \\
\hline \multirow{3}{*}{4} & \multirow{3}{*}{1000} & \multirow{3}{*}{1} & \multirow{3}{*}{3} & 100 \\
\hline & & & & 160 \\
\hline & & & & 110 \\
\hline \multirow{3}{*}{5} & \multirow{4}{*}{800} & \multirow{4}{*}{1} & \multirow{3}{*}{3} & 150 \\
\hline & & & & 120 \\
\hline & & & & 140 \\
\hline \multirow{3}{*}{6} & & & \multirow{3}{*}{3} & 100 \\
\hline & \multirow[t]{2}{*}{800} & \multirow[t]{2}{*}{1} & & 130 \\
\hline & & & & 200 \\
\hline \multirow{3}{*}{7} & \multirow{3}{*}{1000} & \multirow{3}{*}{1} & \multirow{3}{*}{3} & 180 \\
\hline & & & & 170 \\
\hline & & & & 150 \\
\hline \multirow{3}{*}{8} & \multirow{3}{*}{1000} & \multirow{3}{*}{ Pulse Mode } & \multirow{3}{*}{3} & 130 \\
\hline & & & & 130 \\
\hline & & & & 130 \\
\hline
\end{tabular}

Fig. 5 presents oscillogram of sound pressure generated by the transmitter.

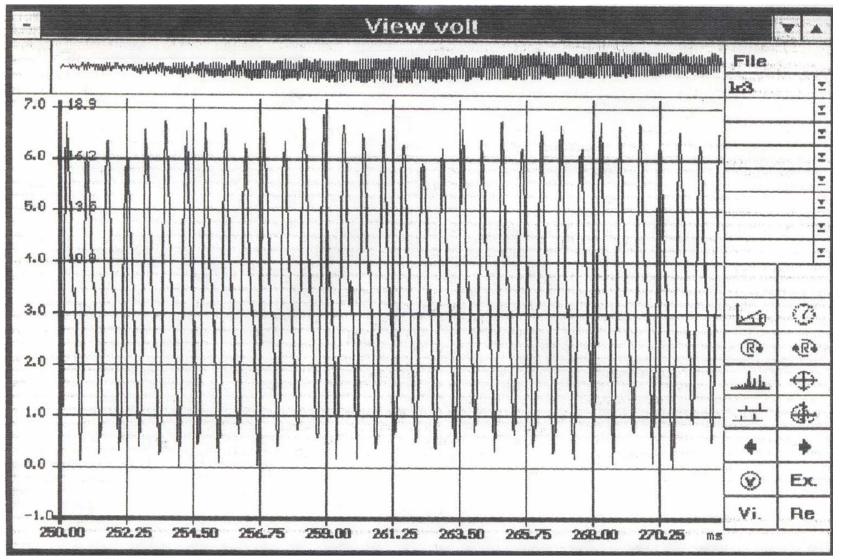

Figure 5. Oscillogram of sound pressure during experiment.

Signal pressure spectrum is presented on Fig. 6 .

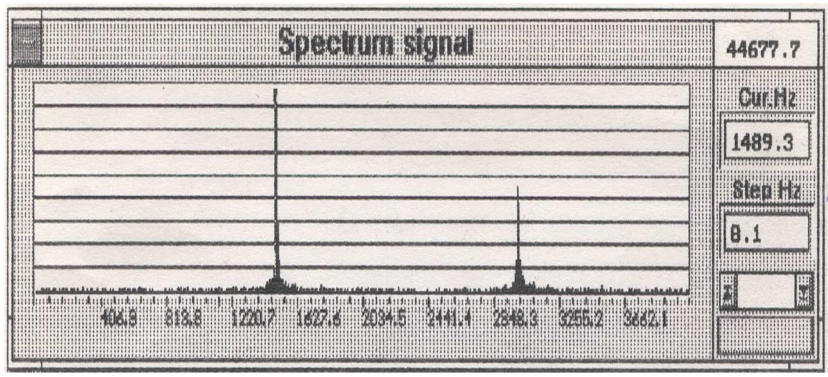

Figure 6. Acoustic signals spectrum

External beetles' investigation directly after an irradiation by acoustic waves, and also in 2, 5, 12 hours has shown that all Colorado beetles remained alive.

It is necessary to note slackness of the beetles subjected to acoustic influence in a mode of radiation of monochromatic waves. Any influence of acoustic waves on a potato at direct survey, and also after time till the harvesting moment had not been revealed. It's important to note that beetles during an experiment in conditions of agricultural area didn't die because the level of sound pressure of the acoustic field inside the concentrator was far below than $120 \mathrm{~dB}$.

The results of this work are of great importance in the study of the relationship between the processes in the atmosphere of the Earth and the biosphere through acoustic vibrations [7-9].

\section{Conclusions}

1. Method and device for Colorado Beetle eliminations was developed.

2. Implementation and testing of the method in conditions of agricultural area was made.

3. The theme is based upon the fact that the resonance frequency of the most important human organs is in the frequency range of $0.5-20 \mathrm{~Hz}$. Resonance frequency and the body stiffness of insects harmful for plants (Colorado beetle) are defined. 
4. Specific influence of low frequency acoustic waves on living beings are reviewed. The theme is based on the fact that the resonance frequency of the most important human organs are in the frequency range of $0.5-20 \mathrm{~Hz}$.

5. Resonance frequency and the body stiffness of insects harmful for plants (Colorado beetle) are defined.

6. At the laboratory conditions, death of the beetle under the influence of vibration oscillations and acoustic waves is determined.

\section{Nomenclature}

$$
\begin{aligned}
& \mathrm{m} \text { - mass } \\
& \mathrm{c} \text { - damping coefficient } \\
& \mathrm{k} \text { - stiffness coefficient } \\
& \delta \text { - deformation } \\
& \mathrm{a} \text { - set acceleration of the body } \\
& \mathrm{t} \text { - time } \\
& \mathrm{f} \text {-frequency. }
\end{aligned}
$$

\section{References}

[1] Бегун П. И., Шулейко Ю. А. Биомеханика. - СПб.: Политехн. $-2000 .-463 \mathrm{c}$.

[2] Сокол А. В., Сокол Г. И. О влиянии низкочастотных акустических колебаний на живые организмы // Акуст. Весн. - 2001. - т.4, №3. С.67-69.

[3] Акустичний спосіб знищення колорадського жука i пристрій для його здійснення: Пат.25548 Україна, МКИ А $01 \mathrm{M} \mathrm{1/04,} \mathrm{А} 01$ М 1/08. А.В. Сокол, Г.І. Сокол, Т.В. Сокол (Україна); - № 97041627; Заявл.07.04.97; Опубл. 25.12.98, Бюл. № $6 .-2 \mathrm{c}$.

[4] Сокол Г. И., Святун А. А. Акустический способ уничтожения колорадского жука. // Праці Міжнарод. Наук.-техн. Конф. «Прогресивна техніка i технологія машинобудувания, приладобудування i зварювального виробництва, присвяченої 100-річчю механіко-машинобудівного і 50-річчю зварювального факультетів»; т. 1- Киев: НТУУ "КПІ", 1998. - С. 107 - 110.

[5] Сокол Г. И. Разработка и исследование акустического способа уничтожения колорадского жука как элемента новой экологической технологии в методах борьбы с вредителями растений. // 4-ая традиц. Науч.-техн. конф. Стран СНГ "Процессы и оборудование экологических производств". Сб. науч. тр. - Волгоград, 1998. - С. 72 - 74.

[6] Sokol A., Sokol G. The Acoustic Method for the Destruction of the. Colorado Beetle // GAMM 99, Annual Meeting (abstracts). - Metz: University de Metz. - 1999. - P.148.
[7] [7] Сокол Г. И., Савчук Т. Л. Взаимодействие акустических колебаний с телами и органами живых организмов / Акустический симпозиум «Консонанс-2011», Киев 27-29 вересня 2011: тези доповідей. - Київ, 2011. - С. 22-23.

[8] Sokol G., Krylova E., Konjukhov S. Influence of Infrasound on the Climat of Earth / Conference of World Climat Research Programme (WCRP) «Climat Research in Service to Society», 24-28 October 2011, Denver, Colorado, USA.- Abstract.Denver, 2011, Session C.8: Atmosphere Dynamics., Posters M $86 \mathrm{~A}$.

[9] Sokol G., Krylova E. Propagation of Infrasound in the Atmosphere of the Earth / Вісник Дніпропетровського ун-ту. - 2012. - т. 20, № 4. - Серія «Ракетно-космічна техніка». 2012. - вип.16, т.2. - С. 36-44.

\section{Biography}

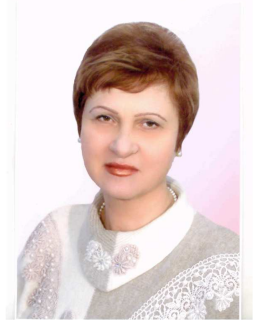

Galyna Ivanovna Sokol received the Diploma of Doctor Technical Science in the Oles Gonchar Dnipropetrovs'k National University (Dniepropetrovs'k, Ukraine) in 2006, Professor of Department of Mekhanotronica 2007. She worked as an Engineer at the "Yuzhnoye" Design Office 1971-1976. She is the author of 350 science papers and inventions, among them there is a monography "The peculiarities of the acoustic processes within the infrasound frequency range", the patent "Acoustic Methods for Distraction of the Colorado Beetle. Elimination of the spices and the Device for its Performance".

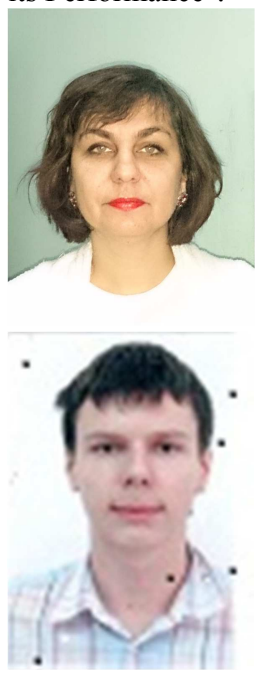

Tatyana Leonidovna Savchuk received the Diploma of an engineer-mechanic in 1998. She worked as an Engineer at the "Yuzhnoye" Design Office in Dniepropetrovsk (Ukraine) in 1998-2004. She is the author of 6 science papers and inventions. Tatyana Leonidovna. Savchuk is engineer of Department of Mekhanotronica of DNU (Ukraine).

Vladislav Valerievich Anisimov is student of Oles Gonchar Dniepropetrovsk National University, Dniepropetrovsk of Ukraine. 